Running Head: DIGITIZING bpNICHOL

\title{
THE COMPLETE WORKS
}

and

DIGITIZING bpNICHOL: STAGING THE WRITTEN WORD IN DIGITAL MOVING

\section{PICTURES}

by

Justin Stephenson B.A.A. Ryerson University 1995

\author{
A thesis project and report \\ presented to Ryerson University and York University \\ in partial fulfillment of the \\ requirements for the degree of \\ Master of Arts \\ in the Graduate Program of \\ Communication and Culture
}

Toronto, Ontario, Canada, 2012

CJustin Stephenson, 2012 


\section{AUTHOR'S DECLARATION}

I hereby declare that I am the sole author of this thesis project report. I authorize Ryerson University to lend this report and project to other institutions or individuals for the purpose of $:$

$\overline{\text { Justin Step }}$

I further authorize Ryerson University to reproduce this thesis or dissertation by photocopying or by other means, in total or in part, at the request of other institutions or indivithals for the purbose of scholarlv research. 
Stephenson, Justin. Communication and Culture, Ryerson University and York University, May 2012. THE COMPLETE WORKS and DIGITIZING bpNICHOL: STAGING THE WRITTEN WORD IN DIGITAL MOVING PICTURES. Supervisor: R. Bruce Elder.

Through a digital cinema project based on the work of Canadian author bpNichol, this paper explores how contemporary poetry provides methods to create, investigate and critique digital images. By examining the way in which digital technology divides images into discrete elements, this report makes the claim that the methods of avant-garde and contemporary poetry align with the methods of digital image making. Using an active documentation methodology in which the working process of the project is documented and reflected upon, this discussion uses sequences from the project to explore how Nichol's writings and poetic methods provide ways to make and examine digital images. 


\section{ACKNOWLEGEMENTS}

This project would not have been possible without the help of several individuals who contributed and supported the preparation and completion of this work. It is my pleasure to convey my gratitude to them here.

First and foremost, I would like to thank Ellie Nichol and The Estate of bpNichol who have supported my project from the very beginning and who have provided me with open access to bpNichol's work and his network of colleagues and friends. Ellie's generosity gave me a great deal of freedom with which to make this project and ultimately allowed me to create a work in the spirit of Nichol's writing. One of the introductions that Ellie made for me was to Brian Nash, who directed the film, $b p$ : Pushing the Boundaries. I gratefully acknowledge his help with the initial stages of the project by providing insights into Nichol's work, for sending me back to my studio with boxes and boxes of logged archival material, and for personally introducing me to a cast of characters that surround Nichol's life and work.

I would like to thank Darren Wershler for providing me with an introduction to Coach House Books, for helping me start my graduate work and for the invitation to contribute the book-cover design for the bpNichol reader, The Alphabet Game. I would also like to express my gratitude to my dear friend and colleague, Michael Phillip Wojewoda who provided pointed feedback, helped with production, taught me about making music on a laptop and always asked about the progress of the project-even when I wished he wouldn't. 
DIGITIZING bpNICHOL

I am very grateful to my supervisor, Professor R. Bruce Elder who nudged me towards making this film project the focus of my studies. Insights from his considerable expertise, our discussions on the importance and relevance of practice based knowledge, and his support and guidance have been invaluable not only to my project, but to my experience as a graduate student and to what I can see as the continuation of this work. I am also grateful to Professor Caitlin Fisher for her introduction to "future cinema", for being on my defense committee and for her insistence on my presence in (not letting me hide behind) the algorithmic animation work that is a big part of my project. I also thank Don Snyder for agreeing to serve as the chair of my committee. I studied with Don many years ago during my undergrad and I always appreciate his presence, questions and insights. I would like to give many thanks to Stuart J. Murray and Michael Darroch who introduced me to a great deal of useful material and who helped me to develop some of the ideas for my project and paper during our seminars.

This work would not have been completed without the input and support of my wife Sheree Stephenson. Her helpful criticism, fearless participation in video shoots, and generous support have made this work possible.

Finally, I would like to thank all of those who helped with the production of my project and with the completion of my paper. I do this while expressing my apology for not mentioning you each here by name. 
DIGITIZING bpNICHOL

For Sheree and Edie, my every( )thing. 
DIGITIZING bpNICHOL

\section{TABLE OF CONTENTS}

Author's Declaration........................................................

Abstract.......................................................................

Acknowledgments.....................................................

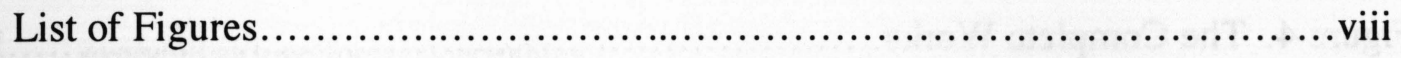

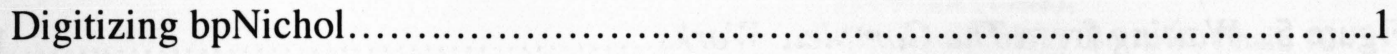

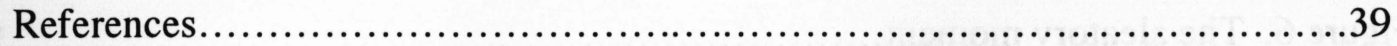


DIGITIZING bpNICHOL

\section{LIST OF FIGURES}

Figure 1. The Complete Works Working Papers - Wordpress Blog.................6

Figure 2. The Complete Works Working Papers - Collages....................... 7

Figure 3. The Complete Works Working Papers - Mind Map.......................9

Figure 4. The Complete Works.....................................................11

Figure 5. Waiting from The Complete Works..................................15

Figure 6. The aleatory moment........................................................

Figure 7. Gorg from The Complete Works.....................................19

Figure 8. The Archival Nichol from The Complete Works..........................22

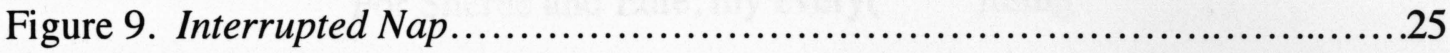

Figure 10. Interrupted Nap from The Complete Works..............................26

Figure 11. White Sound ....................................................... 18

Figure 12. White Sound from The Complete Works..............................29

Figure 13. The Page is a Window from The Complete Works.......................30 
a lens-based recording process flattens the semantic structure of reality - i.e. the different objects that occupy distinct areas of a $3 D$ physical space. It converts a space filled with discrete objects into a flat field of image grains or pixels that do not carry any information of where they came from (i.e. which objects they correspond to)

Lev Manovich (2006),

Image Future

every(all at(toge(forever)once)thing

bpNichol (1982),

The Martyrology Book V, Chain 10

Digital image making allows us to atomize the flattened semantic field of a lensbased image and interrogate the components and materials used to create it. Using digital technology, media from a variety of sources can be easily combined, re-framed, rearranged, re-timed, re-modeled, re-mapped, re-composed, and otherwise recontextualized. The digital image maker can seamlessly incorporate, access, share, edit and recombine imagery in a way that is akin to an author's manipulation of the written word (Lessig, 2008).

Avant-garde and contemporary poetics provide strategies for the interrogation of meaning making in the text. By challenging language as a transparent vessel for the communication of meaning, contemporary poetics not only make visible the conventions and expectations around language usage, but also render visible the material of language. Through a discussion of my digital cinema project, The Complete Works, based on the work of Canadian author bpNichol, this paper will examine digital image making practices using the methods and strategies of contemporary poetry.

bpNichol was an author who was active in the Canadian literary scene from the mid 1960s until his death in 1988. He began his career with the desire to write novels and 
prose. In an interview with Phyllis Webb (Nichol \& Webb, n.d.) he stated that he thought the way he could become a good author would be to "tighten up on language" by writing lyric poetry. At a certain point, however, he discovered that, "no matter what mood I was feeling in, I would sit down and out would come this depressed lyric poem. I thought, well, I'm just plugging into a form" (ibid.). From this realization, he became interested in the relationship between form and emotional content and the reading as a performance. This led him to work with a wide range of genres: books of poetry, theoretical essays, children's stories, operas, television scripts, early Apple II computer poems, novels, sound poetry, visual poetry, comic strips - a veritable catalogue of textual strategies, techniques and processes. For Nichol, the connection between form and content in the poem were intertwined, "If I can keep moving the structure of the poem around, hopefully I can encompass different realities and different ways of looking at things" (2002, p. 276). His body of work provides a rich resource of textual strategies to interrogate how the poem, the rules of language and the materiality of the text shape meaning within the text.

bpNichol's was not the only writer exploring these themes. While there are examples of poetics being used to interrogate language usage that dating from antiquity (Higgins, 1987) the poetics of the avant-garde identifiably make this a focus. Rather than creating a poetry that positions the poet at the center of the poetic writing, sharing unique observations about the world (Perloff, 2010), avant-garde poetics interrogate the function and qualities of texts, how they work, and what role of the author and the reader play in the text. These interrogations take the form of manipulations to the structure of language, the materiality of the word, and the printed page. The strategies employed in these 
DIGITIZING bpNICHOL

explorations and interrogations resonate with the types of configurational action-the manipulations of pixels - that are employed in digital image making (Cayley, 2004; Lessing, 2008). For this reason, Mallarmé, Apollinaire, Italian Futurism, Dada, Russian Constructivism, Letterisme, concrete and visual poetry are often put in a genealogical lineage with digital media poetics (Golding, 2006).

Friedrich Block expands this genealogical connection, citing the poetic manifestos of the ' 50 s and ' 60 s that prioritize self-reference by language and "sign complexes" (2007, p. 235). Block argues that avant-garde poetics can be said to deploy selfreflexivity as a strategy to symbolize symbolizing - staging the poem's use of language. The language usage, the structure (narrative and otherwise), the genre, and the materiality of the poem become "content" or meaning in the poem. Gillian Rose (2006) lists a number of compositional characteristics of an image that can be identified as contributing to the meaning and effect of an image. When dealing with digital images, characteristics such as superimpositions, filtering, depth of field, camera angle, shot distance, and lighting, for example, are not simply compositional characteristics of a flattened image, but can be seen as discrete elements that can be easily manipulated. The image becomes as malleable as the text (Cayley, 2004), and each "sign complex" in the image can be discretely staged as symbolizing. In this context, the strategies of avant-garde poetry provide creative strategies and a framework for the practice and interrogation of digital image making.

Advances in digital moving image technology have lead to the increasingly frequent appearance of hybridized forms of media (Manovich, 2007). The hybrid combines different media, for example typography, animation (computer generated or 
hand drawn), graphic design and camera-recorded images. This hybridization of media can be foregrounded in collage-like visual strategies, or it can operate in the background as a method of building "realistic" or hyper-realistic scenes. "Pure" moving-image media, meaning time-based images recorded by a camera that have not been modified or combined with other media in postproduction, is increasingly rare. While these media hybrids have been commented on extensively as special effects in Hollywood narrative films, Manovich (ibid.) points out that there has been no formal analysis of these media hybrids or intermedial forms outside of narrative films. He contends that the reason is that no new media are actually created in this hybridization process. For Manovich, the hybridization of media shifts the language of already existing media which is less visible than creating a "new-media".

My practice-based study is located in this gap identified by Manovich. The Complete Works explores media hybrids and the way they create meanings by staging the writing of bpNichol in digital moving image media. Given the stylistic, formal and technical range of Nichol's work, this task requires an equally wide range of formal and technical devices in digital moving image: from graphic animation to live action, procedural animation to $3 \mathrm{~d}$ computer generated images. My project traverses a range of unique media hybrids that embody interactions between textuality, visuality and "digitality."

Practice-based work is a contentious, but growing, area within scholarship. I argue that the production of this digital cinema piece has generated unique and specifically valuable knowledge that could not be obtained in another manner. The act of translating Nichol's work into digital moving images opens a rich field of investigation, 
DIGITIZING bpNICHOL

interpretation and engagement in the interaction of text and digital media that would not be visible through a traditional close reading. The Complete Works is an embodiment of a developing theoretical discourse on the interaction of digital image making and avantgarde poetics. I approached the development of the project as a scholarly design process (Archer, 1979; de Freitas, 2002; Marshall \& Newton, 2000; Scrivener, 2004).

The design process, as described by Clive Dilnot (1999), is not concerned with what can be measured or known, but with being able to grasp, "the nature of the (series of) complex configurative acts that secured the phenomenon as such" (p. 31). Design possibilities are enacted translations and transformations of propositions to actualizations. These translations and transformations involve the practical manipulation of media and materials which, when identified and interrogated, produce knowledge. While it is not knowledge through the traditional paths of "The Three Rs" (reading, writing and 'rithmetic [sic]) (Archer, 1979), it does constitute a way of knowing expressed through the act of making and doing.

Aspects of this "knowing through making and doing", "design-knowledge" or "practical-knowledge", will be translated in the following sections of this paper through a reflective-practice methodology as laid out by Nancy de Freitas (2002). She proposes "active documentation" as an effective way of translating practice based knowledge to scholarly knowledge. Active documentation is just that-documenting the work and work episodes with a series of goals in mind (de Freitas, 2007). The goals are: first, to identify the evolution of the work; second, to report challenges, accidental discoveries, and improvements; third, to articulate aspects and phases of the work that are made invisible by the progress of the work; fourth, to provide a detached record for the 
abstraction of the issues of the study. The active documentation for this project employs the web-based blogging tool, Wordpress (Figure 1). This tool allows for the easy collection of notes, images, sounds, animated tests and digital code fragments.

Figure 1. The Complete Works Working Papers - Wordpress Blog. (Stephenson, 2012) from http://justinstephenson.com/wp/

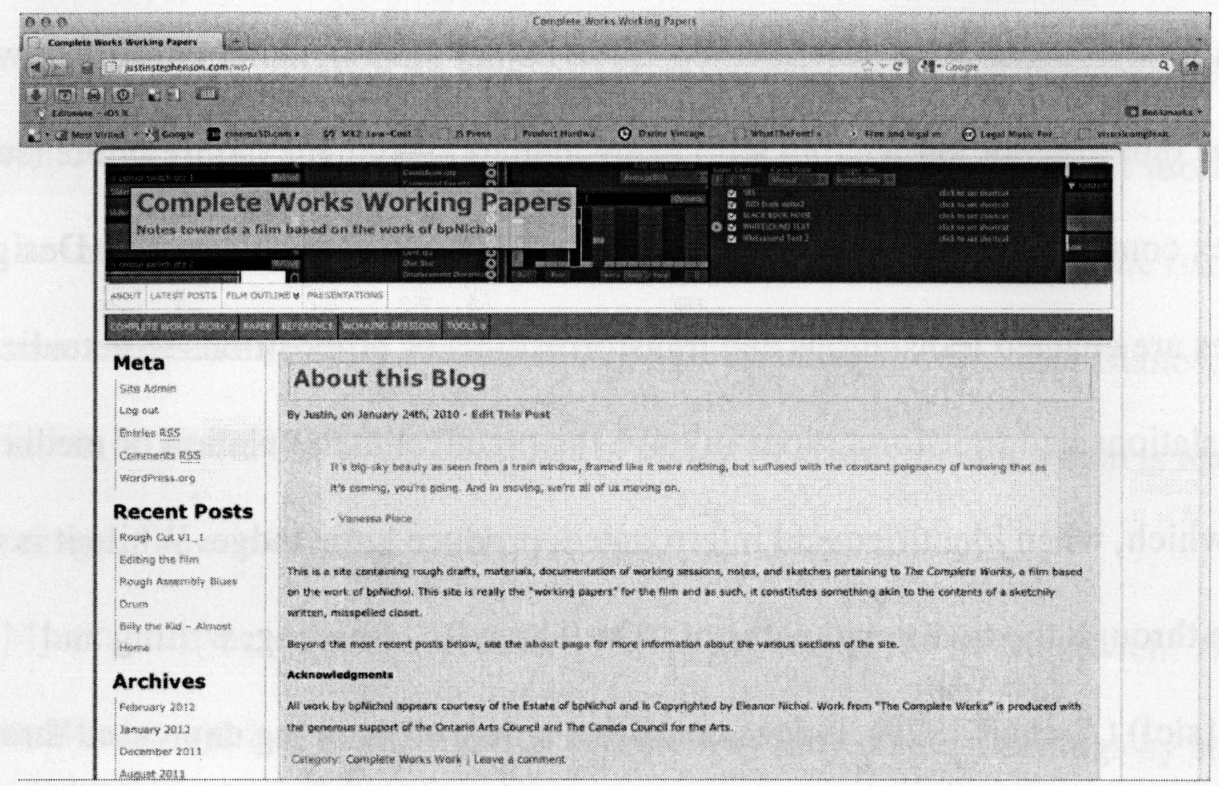

I will situate this discussion in four currents I have identified in my digital cinema project, The Complete Works.

1. The ways in which collisions and hybrids of media highlight the material and structural qualities of digital moving image and the text.

2. The deployment of self-reflexivity as a way of foregrounding the text and the role of the reader in the production of the meaning in the text.

3. Image-text relations as a dynamic field of interrogation between imitation and signification. 
DIGITIZING bpNICHOL

4. The ways that the textual practice of quotation informs the digital practice of remixing.

I will start with an outline of how the project started and then explore these four currents using sequences from the film. Throughout the discussion, I will draw upon a range of theoretical work to discuss issues brought up in the course of making the project.

Figure 2. The Complete Works Working Papers - Collages. (Stephenson, 2012) from http://justinstephenson.com/wp/2009/02/09/initial-collages
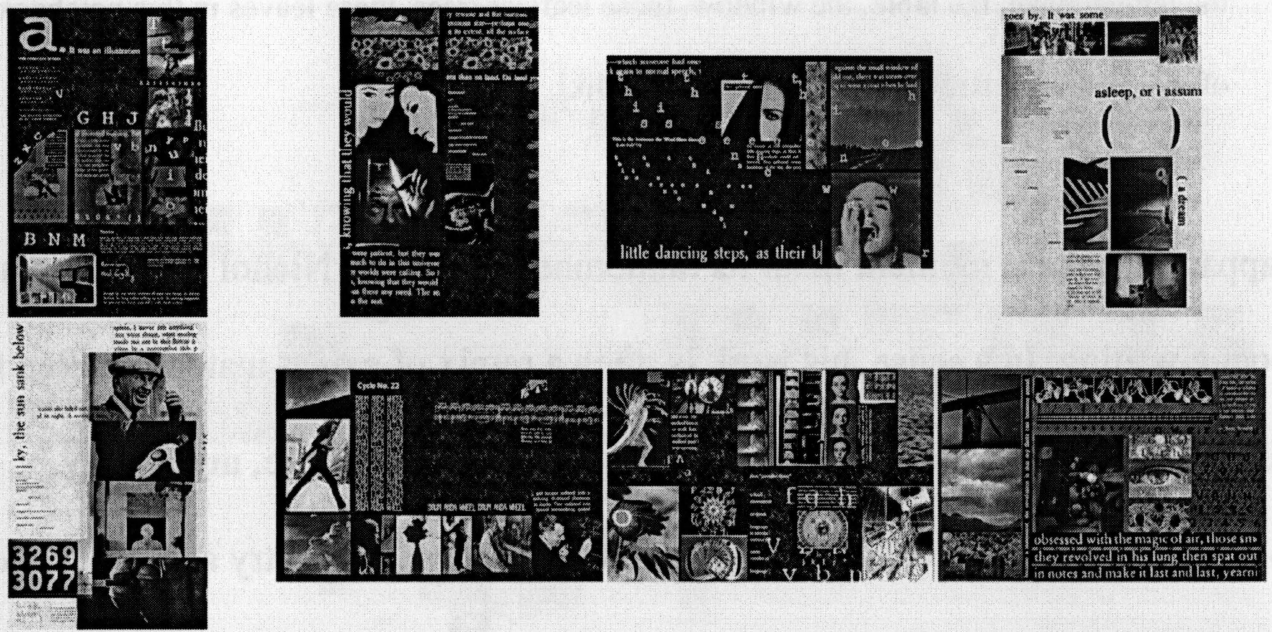

This project began with a selection of Nichol's writing chosen partly for their thematic content, partly for their importance to his oeuvre, and partly simply because I liked the work. I then produced a number of analog collages (Figure 2) based on Nichol's poems using images from a number of sources - largely magazines. In many respects, this process gave me the opportunity to learn more about the relationships between Nichol's work and my own moving image practice. This early collage work provided a basis from which to work with Nichol's poetry by helping me to articulate the emerging interests and concerns of the project. 
DIGITIZING bpNICHOL

Nichol often drew upon his immediate surroundings for raw materials for poems. For example, he would use what he saw out the window, what he discussed with friends, what he overheard in conversations, or what pieces of music he listened to:

At a certain point you decide to start with what's in front of you. There's no point despairing of a subject, or carrying on some misguided search for a "great" theme when all you have to do is start with what's in front of you: the blue lines, the ink, the pen, the letters the pen shapes, the words the letters make, the table, the window, those leafless trees, these leaves in this notebook in front of me, you-the stuff of poetry. (Nichol in Miki, 1988, p.35)

The apparent present moment in all its randomness provided Nichol with raw material for the poetic writing. In a sense, his work is often a remix of extant material pulled from his immediate surroundings and other sources: history, quotidian life, mythology, cartography to name a few. Nichol viewed the act of writing poetry as a process of generating meaning rather than as an expressive act-the poem was not something that depended on inspiration, nor was it something that one composed to create a determinate message. Poetry, for Nichol, is a method of engagement (Nichol in Miki, p.37).

I started the process of making The Complete Works with performances of Nichol's work. The plan was to use these as the basis for a translation of his work into moving image. Rather than seeking performances of work that I selected for my own compositional reasons, I engaged a number of authors who were colleagues of Nichol's and asked them to participate by performing a reading of a bpNichol piece of their choosing. I felt this would be more in keeping with Nichol's methodology of engaging the poetic writing by using material at hand. The poems in the film would have 


\section{DIGITIZING bpNICHOL}

something of the character of found material, for I would not stipulate what these authors read. In the process of travelling to shoot the performances with the authors, my cinematographer, John Mihn Tran, and I shot a wide range of footage from our travels. These images formed a visual travelogue and provided raw material for subsequent explorations in postproduction.

Figure 3. The Complete Works Working Papers - Mind Map.

from http://justinstephenson.com/wp/cw-film-outline-2/cw-film-outline

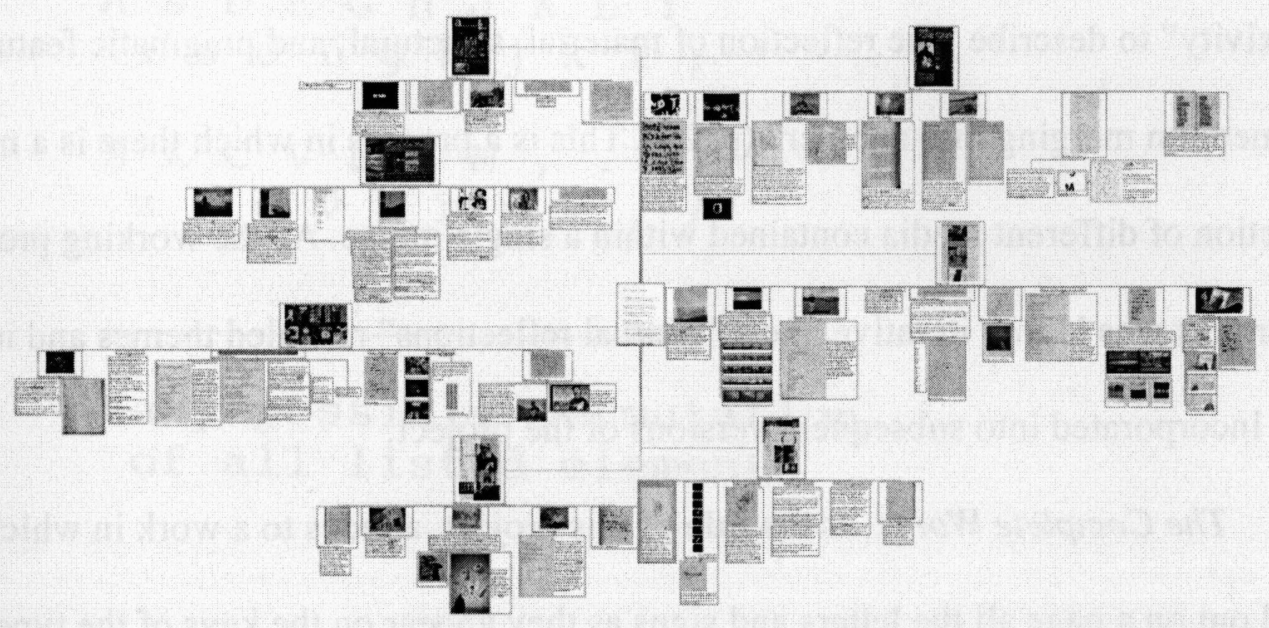

With the collection of works chosen by myself and the authors, I created a large digital mind map of the available material for the project (Figure 3). This mind map collected my notes, animation and sequence ideas, Nichol's poetic materials, visual references and performances into a set of constellations (Goldsmith, 2011). The mind map provided a guide throughout the production process for the poetic and thematic scope, potential collisions and connections between textual, and moving image strategies and concerns. 
DIGITIZING bpNICHOL

Translating bpNichol's work to moving image creates collisions of different media. Marshall McLuhan (1994) stated that these collisions of media create hybrids that give us the opportunity to examine the structural aspects of each of the component media. Petr Szczepanik (2002) expands on this by stating that the collision of media leads to a defamiliarization of, "the hidden or automatized structural components of both media" (p. 29), making them visible to the viewer/audience and allowing us to reflect on the dialogue that takes place between media. Szczepanik uses the term "intermedial reflexivity" to describe "the reflection of material, structural, and pragmatic features of one medium merging into another" (p. 29). This is a process in which there is a mutual reflection of different media contained within a single image. As the working process of my project was highly iterative, these "mutual reflections" revealed themes and ideas that were incorporated into subsequent versions of the project.

The Complete Works, as the title of this project, alludes to a work in which Nichol typed out on a page all the letters and signs as they appear on the keys of the typewriter with the footnote "any and all permutations of the above listed elements" (Figure 4). Complete works anthologies presume to collect a selection of the life's work of an author. In The Complete Works, Nichol's complete works are not a series of texts but the system that he uses to create those texts, pictured as the QWERTY arrangement of the keys of a typewriter. As in Borges' Library of Babel (1998), The Complete Works posits Nichol's life's work as a permutation of the signs available on the keys of a typewriter. This is not simply the alphabet. It is specifically the alphabet as it is laid out on a typewriter, which divides letters, numbers and punctuation into separate keys, and standardizes the spacing, size, and font. 
DIGITIZING bpNICHOL

Figure 4. The Complete Works (Nichol, 1980, p. 39).

TIIE COMPLETE WORKS

\pm ( \# \# $\$$ \% c \& \& * ( )
$1223445678890_{-}^{+}=$

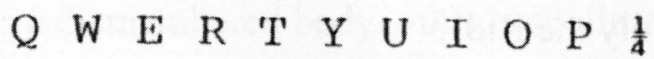

$q w$ e $r$ t $y$ u i o p $\frac{1}{2}$

A S $S$ D $F$ G

a $\mathrm{s}$ d $\mathrm{f} \mathrm{g} \mathrm{h} \mathrm{j} \mathrm{k} 1$;

$\mathrm{Z} X \mathrm{C} \quad \mathrm{V}$ B N M, ?

$\mathrm{z} \times \mathrm{C} \quad \mathrm{v}$ b $\mathrm{n} \mathrm{m}$, , /

*any possible permutation

of all listed elements

The typewriter transforms the act of writing into an act of selection and combination.

This has far reaching implications into the traditional notion of poetic production. As

Nietzsche put it, "Our writing tools are also working on our thoughts" (in Kittler, 1999, p.

200). In Nichol's The Complete Works, he emphasizes the poem as mediated by the media in which is produced.

Nichol's The Complete Works explores his poetry as mediated through the typewriter and the written word. Darren Wershler (2005) contends that the claim the typewriter can be a precise recorder of the poet's intention, a device that can score the presence, breath and speech of the author, ignores the important fact that writing on the typewriter highlights the mediation of the writing through technology. The typewriter 
filters the writing through a defined number of discrete keys, which produce discrete characters on a page that is divided up into discrete cells. It transforms the writing into a permutation of a fixed set of signs arranged into a discretely defined distribution of space. I wanted to begin this project with a picture of the poem as always mediated and always part of a previously existing semantic system as opposed to a "pure" or "true" expression (as we will see later in his work on Billy the Kid).

The Complete Works sequence is a playful take on a filmic report of the typewriting act. At its core, it is a simple set of elements: the sound of typing, moving image footage of the keys being pressed, the internal mechanics of the typewriter and the resulting letterforms on the page. The sound of the text being written on a typewriter highlights the mechanics of its production. Each key on the typewriter is a discrete sign but the sounds the keys make when they are pressed are not the sounds of the signs themselves but the more homogeneous sound of the machine impressing the sign onto the page. In the typewriter, all the signs are produced with essentially the same mechanical action. Using digital sampling, these sounds can be divided into discrete units and composed into any rhythm one might like-not just the rhythm of typing a text. Using typewriting sounds, the composer, monSTars ARe LIke That [sic], created a rhythmic piece entitled, “A Prepared Piece for 4 Typewriters” (2011), which alludes to John Cage's compositions for what he called "prepared piano." The title of the composition really describes the methodology of a "prepared" piece. It divides and reconfigures the sound of the production of a text to create a new work.

The digital cinema version of The Complete Works maps images of typewriting to reconfigured sounds of the production of the text. Nichol's The Complete Works, divides 
DIGITIZING bpNICHOL

the text into its component elements as defined by the technology of the typewriter. This methodology applied to a moving image points towards the frame as the atomic unit of the recorded image. The frame in a moving image records the action by dissecting movement into individual moments at the rate of $24,30,50$ or 60 times per second in the standard digital moving image formats. Fredrick Kittler (1999) stated that the filmstrip really captures a dismembered body - this is similar to the way in which The Complete Works captures a dismembered text. As a collection of individual frames, the image is no longer required to simply represent the recorded action. It can be arranged based on alternative composition constraints - in this case, the rhythms created in a musical composition based on the sounds of a writing machine.

Dividing a continuous flow of words, speech, movement, or image into atomic components - exploding the text into letters, the moving image sequence into frames, the frame into pixels - opens up the possibility of recombining a work along a radically alternative axis of organization. Richard Cavell, in McLuhan in Space (2003) highlights the manner in which Nichol's work regularly ruptures the linearity of text in the way he dispersed it over the page. Nichol stated in an early draft of The Martyrology (his lifelong long-poem spanning some 9 books), "Density Does not Work-flow of poem demands thin pointillist usage of words" (Niechoda, 1992, p. 33). Cavell likens Nichol's use of language to Seurat's "pointillism" in which tiny little dots were used to construct the image in a manner that was "anti-perspectival". Pointillism positions the viewer/reader at the vanishing point of the work and therefore makes them active participants in its construction. Cavell continues to discuss this idea in relation to atonality: 
DIGITIZING bpNICHOL

Using atonality...(as in acoustic space) wherever you are at the moment is the key you're in, the tonal center, and the governing consideration is the nature of and affect on the overall pattern.

Such a space is not uniform but rather a multidimensional dynamic of figure and ground. (2003, p.

Nichol's poems Waiting (1978) and Gorg: A Detective Story (ibid.), create "multidimensional dynamics of figure and ground" positioning the reader and moment of reading as active participants in the action and meaning in the text. Nichol does this by putting readers in a position to face their own expectations in the text. An example of this can be found in the way he uses invented quotations in The Martyrology. We read such quotations as referring to the view of someone who has something authoritative to say on the subject of the text. The discovery that the external quote is an invention of the poet places the reader in a position to face the manner in which these quotes are read. Waiting and Gorg: a detective story implicate the reader and the act of reading using two different strategies.

In Nichol's Waiting, the text directly addresses readers, implicating them in the creation of the meaning in the text.

i am only when i see these sequences of letters endlessly the same if you forget your you completely then i am most completely anything you do beyond this is outside my existence, outside my awareness, does not matter to me (1978, waiting, para. 17)

In The Complete Works, I used Waiting to explore the contingencies of the reading. It is composed using printouts of the letters from The Complete Works. These letters were gathered together and thrown into the air. Their flight was recorded using a Phantom Flex high-speed camera by Vision Research. This camera allows one to capture a 2650x1600 pixel image at 1500 frames per second. 
DIGITIZING bPNICHOL

Figure 5. Waiting from The Complete Works (Stephenson, 2012).

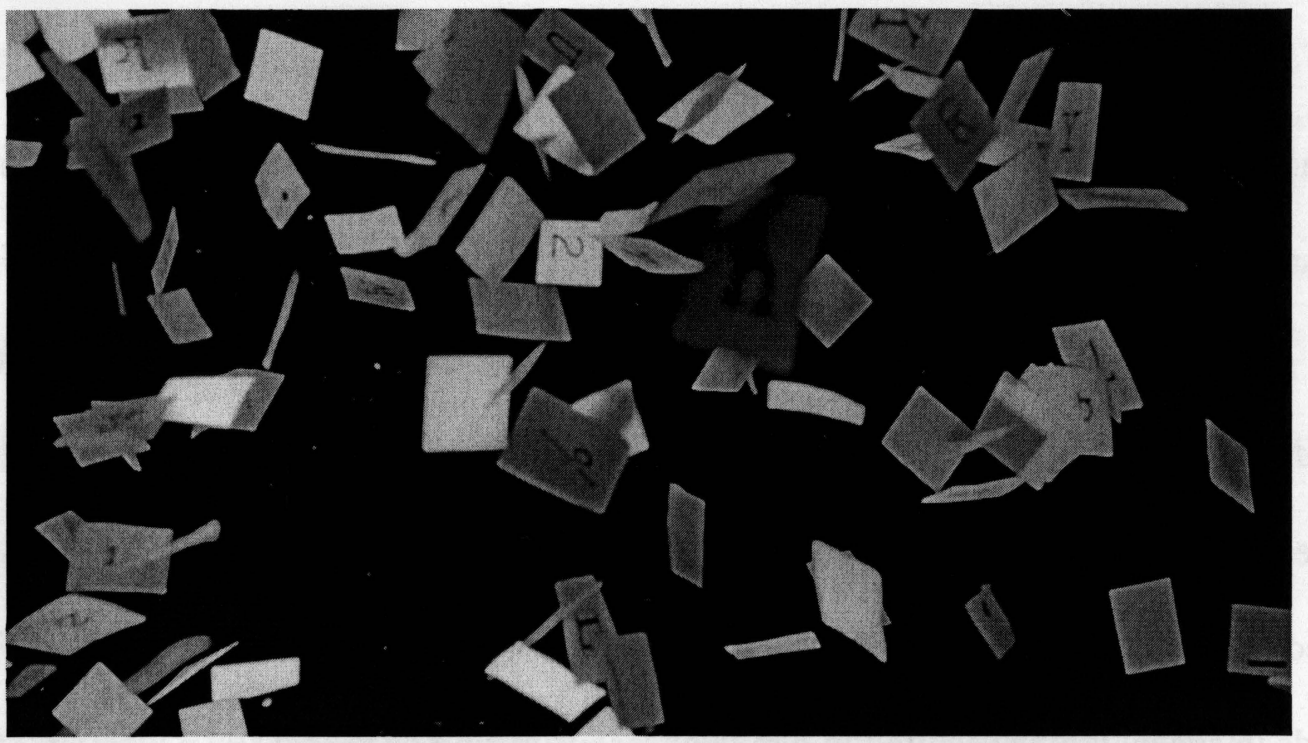

At that rate, the 4-second shooting buffer becomes approximately 4 minutes at 24 frames per second. This camera technology was designed as an engineering instrument. On the VRI website, their "About" blurb describes the impetus behind the technology:

High speed photography is an engineering tool, much as is an oscilloscope or a computer. It is a photographic technique that enables us to visualize and analyze motion. Especially motions that are too fast for the human eye or conventional cameras to perceive. (Vision Research, 2012)

The high-speed camera distorts time by increasing the rate at which it captures individual frames of an event, for example 1500 times per second. This very high temporal sampling is then played back at a reduced rate, specifically $24 \mathrm{fps}$. The result allows us to see things that happen too quickly for direct perception. It is a tool for slowing an action down to reveal what cannot be seen by the unaided eye. It introduces "a waiting" into an event that would normally appear instantaneous. In this case, the 
instantaneous is the reading of the word within the text. The film version of Waiting slows the reading down to reveal the letters as the atomic units of the text. It juxtaposes Nichol's depiction of the text as a solid substance waiting to be brought to life through the act of reading against the endless dynamic in the contingencies of a reading.

Simon Morris, in his piece, Royal Road to The Unconscious (2011), cut out all the words from Freud's book, The Interpretation of Dreams, placed them in a box, and hurled them from the window of a car driven by psychoanalyst, Dr. Howard Britton, at a speed of 90 miles per hour. This "aleatory moment" produced an explosion of 223,704 words in space, which resulted in a radical reconfiguring of the text as a "stream of words strewn along the side of the road" (Morris, 2003, para 2).

Figure 6. The aleatory moment (Morris, 2003).

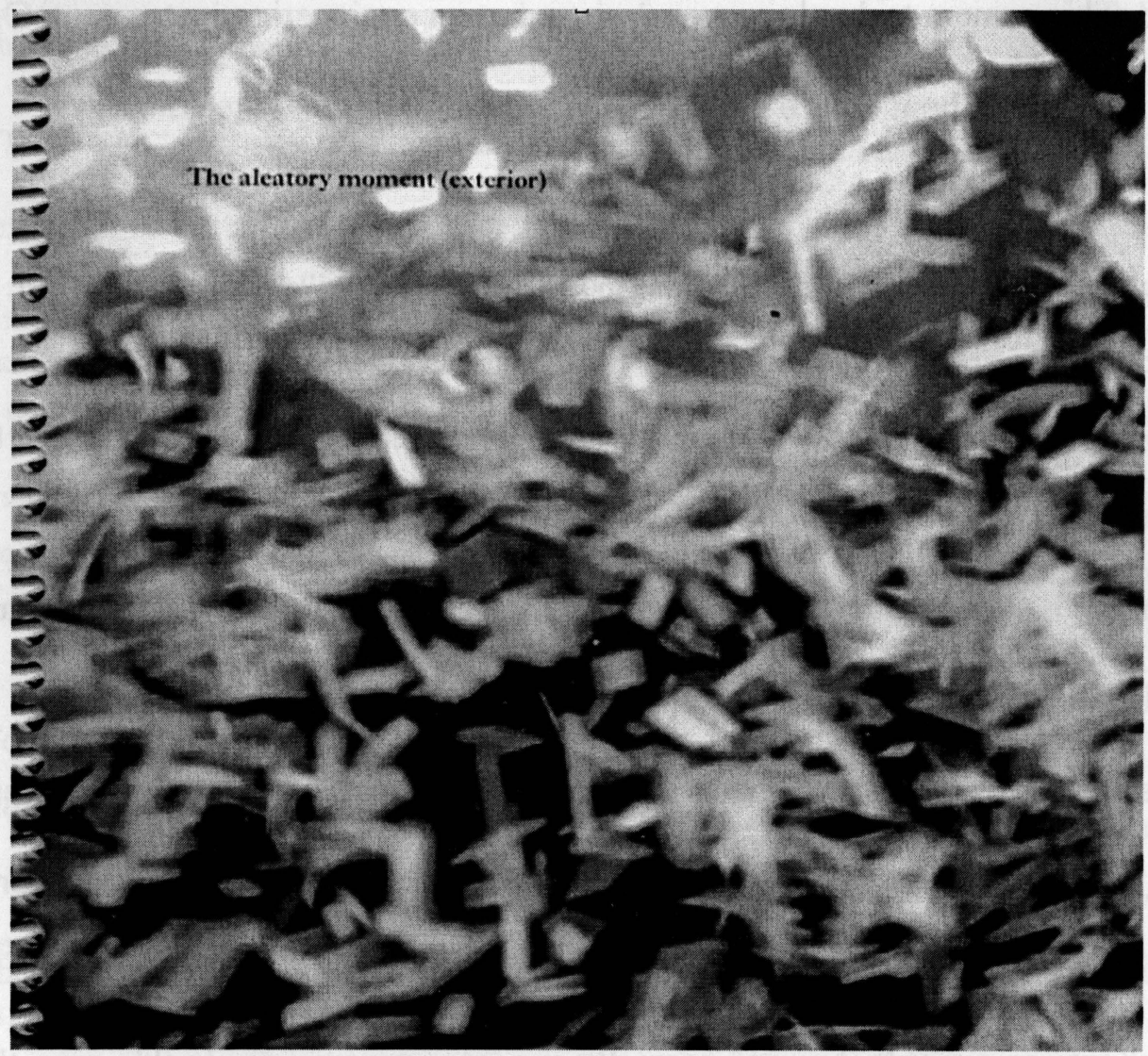


DIGITIZING bpNICHOL

Psychoanalyst Dr. Howard Britton directed the artist to "ruptures of the Real" in this new text. "The Real” Morris is referring to is Jaques Lacan's order of the Real which is the aspect of experience that cannot be put into language or otherwise symbolized (Botting, 1994). In his artist statement, Morris calls this piece "The poetic act of liberating Freud's text [which] allows us to engage with Lacan's register of the Real" (2005, p. 6) which he sees as being an "encounter beyond images and words" (ibid., p. 7). Morris's piece portrays the liberation of the text as an explosion. The configurational action of the text happens so quickly it appears as an instantaneous moment of chaos from which new texts are created. The moving image version of Waiting used an engineering instrument to situate us inside that explosion. Waiting is not about the liberation of the text as an explosive action, but as a careful act of reading:

\footnotetext{
we have begun we have begun again as we did before so many times each time you are different each time there is something about you that is different i am always the same always the flow which is your vision of me which is my vision of me is the same (1978, waiting, para. 2)
}

In Waiting, while the text may be the same in the book, the act of reading brings with it the possibility of a rearrangement, or a reframing of the text down to the letter. Morris's piece locates the reconfiguration of the text in the unconscious. Waiting, through an act of temporal distortion, lets us see the insistence of the letter in the poem and the reading of the poem. This is a theme and concern that can be seen throughout Nichol's poetic. "i am only when i see these sequences of letters." (ibid.) As Jaques Lacan states (Lacan, 1966), language does not express consciousness, it brings consciousness into being-rather than I write language, language writes me. The poem is not written in 
DIGITIZING bpNICHOL

language, the poem is written by language. Waiting casts the "life" of the poem as a sequence of letters that bring into being not only the poem, but also the reader.

Gorg: A Detective Story uses a different strategy to foreground the act of reading. In Gorg, the reader is "drawn" into the story (in both senses of the word) through the twists and turns of a detective narrative. "A man walks into a room. There is a corpse on the floor" (ibid.). As the poem unfolds the text leads the reader to inhabit each of the characters in the story. We become the murderer, the victim, and ultimately the detective.

Gorg highlights the action of pronouns in the text by deploying the reader to complete the identities of the characters in the story. The act of reading "draws" the "I" into the story. Emile Benveniste discusses this action in language, "I can only be identified by the instance of discourse that contains it and by that alone" (1971, p. 218). "I" is a signifier for the identity of the speaking subject, or in this case, the reading subject in the moment of reading. "you are lying on the floor dead. You have been shot through the temple the bullet exiting almost through the top of your skull" (Nichol, 1978, Gorg.)

The language and tone of Gorg recall the comic book. It uses a montage of short statements written with visual language to build a narrative picture. In the comic, graphic simplification, sequences of imagery, transitions from panel to panel, and word/image relationships absorb the reader/viewer in an immersive verbal/visual environment. As Scott McCloud puts it, "the cartoon is a vacuum into which our identity and awareness are pulled [...] We don't just observe the cartoon, we become it" $(1994$, p. 36). It is an absorptive medium. Gorg complicates this "becoming" of the cartoon by making us aware of our position as reader. To use Charles Bernstein's description, Gorg creates a 
tension between the absorptive qualities that make the text appear transparent by drawing the reader into the story and the anti-absorptive qualities which foreground the materiality of the text, mechanics of the poem and the role of the reader in creating the story. Nichol accomplishes this by drawing our attention to the "artifice of absorption" (Bernstein, 1992).

Figure 7. Gorg from The Complete Works (Stephenson, 2012).

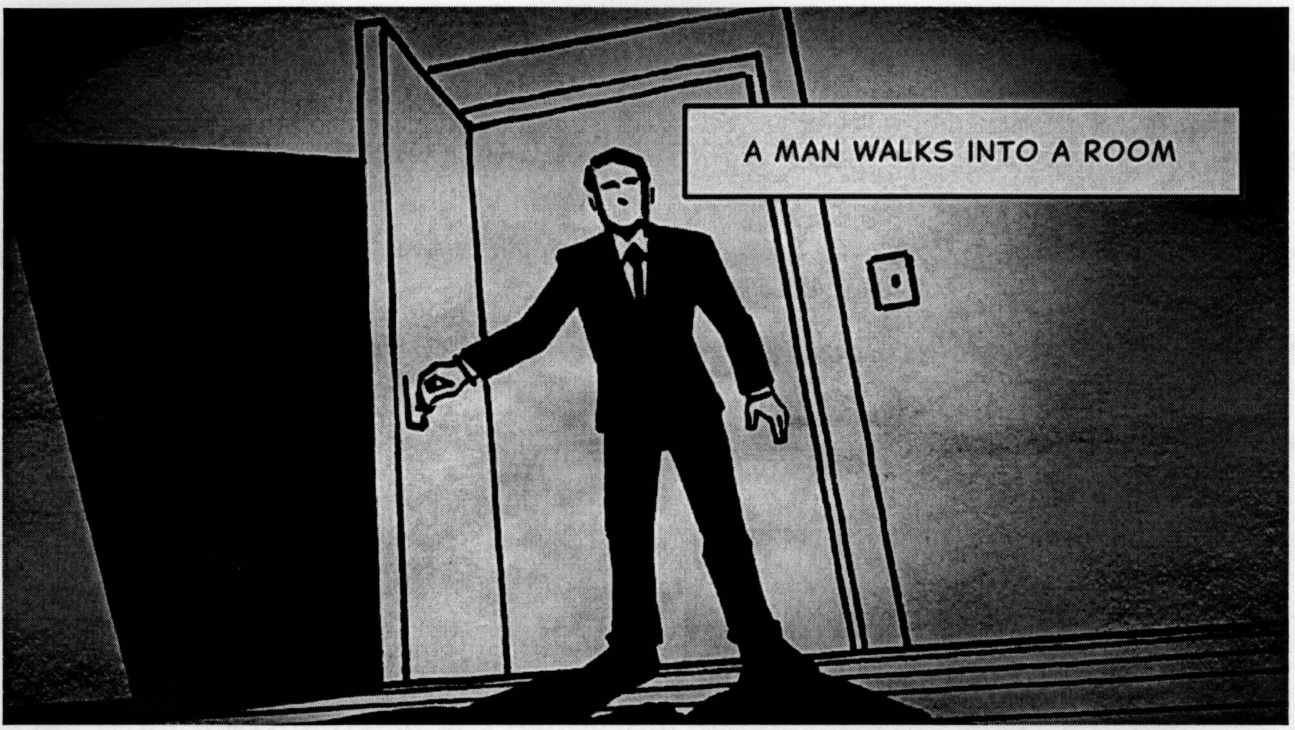

The Complete Works version of Gorg pictures the text as a comic. Illustrations based on the scenes in the poem-characters, settings and props-are placed in a threedimensional space and explored with a "camera." This "motion comic", as it is called by comic publishers (McBride, 2008), presents the illustrations as if they had existed in front of a lens. This introduces lens-based realism to the scenes. This is emphasized by using lighting, tonal gradations and paper texture. We are no longer looking at an illustration; we are looking at a three-dimensional environment in the way that a camera would see it. The recursive qualities of the narrative can be mapped to these material points in the sequence: the eye of the camera, the illustrated scenes, and the text. All of these elements 
work off of each other to mirror the tensions in the poem between the absorptive qualities, and the anti-absorptive qualities. As one would follow the action in a detective comic, Gorg asks the question of what is a meaningful clue and what is not. In the end, it arrives back at the reader and the instance of the reading as the site of the production of that meaning.

The relationship of image and text is an ongoing concern in Nichol's work, as can be seen in the series of books Zygal: a book of mysteries and translations (1985), Truth: a book of fictions (1993), Art Facts: a book of contexts (1990), Love: a book of remembrances (1974). In his text-based poetry, the visuality of the text on the page contributes to the manner in which the poem is read. He often pictures the text and the letters that make up the text interacting with each other and with various illustrated characters. Examples of this can be seen in the series of works Allegories and Frames in Love: a book of remembrances (1974). Picturing text uses the logic and surface of pictures to visualize the structural elements and associative rules of language. This could be considered a form of visual onomatopoeia in which the image imitates language. Derek Atteridge in his essay Language as Imitation (1984) argues that onomatopoeia is a "momentary and surprising reciprocal relationship between the phonetic and semantic properties [of language]" (p. 1127). If we replace the term phonetic with photographic here, onomatopoeia provides a way of "picturing language" in the image by using imitation. This becomes a key element in the later discussion on sound poetry and audio reactive visuals. In the reciprocal relation between the visual and semantic properties we can picture language in the act of producing meaning. 
DIGITIZING bpNICHOL

In The Complete Works, there is an archival recording in which Nichol describes his poetic trajectory from the lyric poem to a poetry that explores the links between formal and material qualities of the text and emotional content. During this segment, the visuals are based on an archival series of photos of a young bpNichol walking along the beach. This segment builds on a book cover I designed for a reader of his work, The Alphabet Game (Wershler \& Emerson, 2007). Using a variation of the compositing technique seen in Gorg, the foreground and background in the archival photos are separated and placed on different three-dimensional planes.

Computer-generated three-dimensional letters have been animated and composited within the scene of the archival photograph. They hang in the sky over Nichol and the beach, slowly rotating in space. In digital compositing, the brightness, transparency and opacity of the letters are matched to the lighting in the photograph and algorithmic film grain has been added. Both of these compositing techniques are used to integrate the letter into the scene in a believable manner (Figure 8). In addition, real water and an animated camera with a "hand held" sense of movement is used to give the scene the kind of immediacy that one might get from a home movie. This combination of techniques creates a tension between the historical, archival bpNichol and the "digital Nichol" of my project.

As Nichol discusses the necessity of using different formal strategies to encompass different states of mind, the image pictures the letters of the alphabet as a real physical part of the environment. This segment outlines the reciprocal relationship between Nichol's work and my digital cinema project. It presents a scene in which representation by signs and representation by resemblance creates a dynamic space of 
DIGITIZING bpNICHOL

interpretation that is akin to an inverted calligram - the letters are "pictured" as opposed to being used to create a picture.

Figure 8. The Archival Nichol from The Complete Works (Stephenson, 2012).

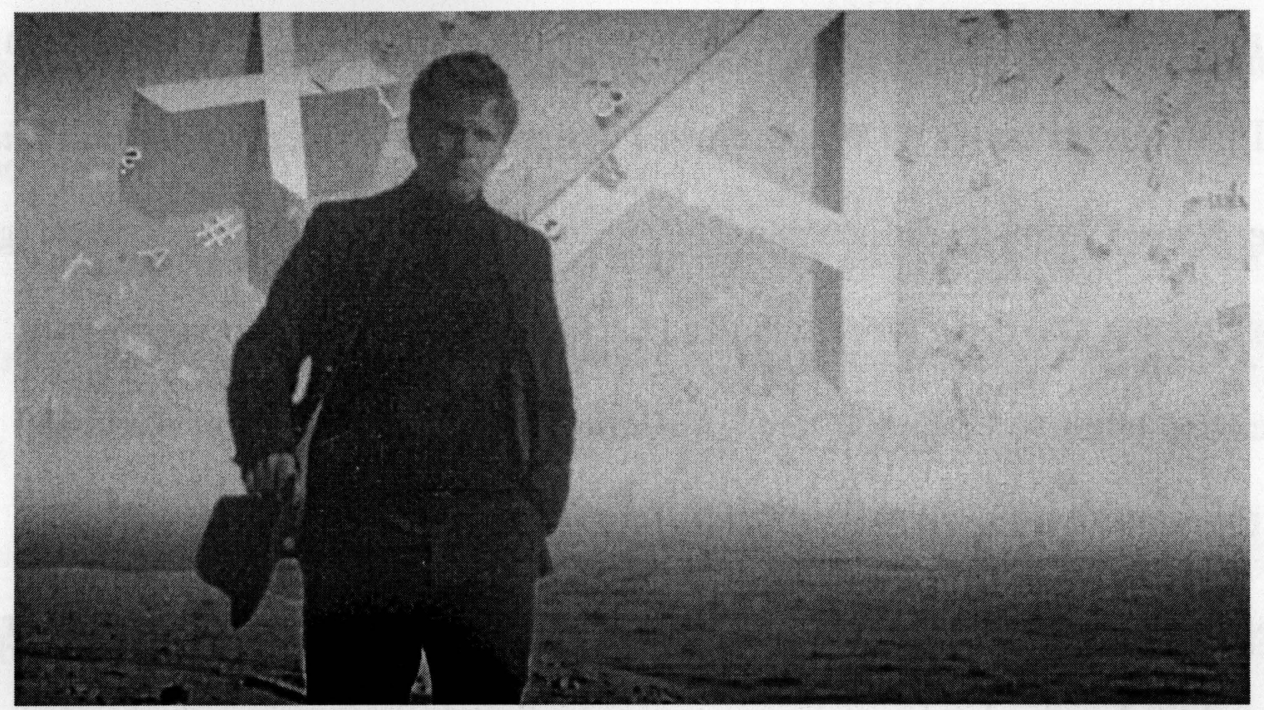

Calligrams are texts in which typography is used to create images. Michel Foucault, in his book, This is Not a Pipe (1983), describes the calligram as alphabetizing the ideogram, replacing the continuous lines in a graphic with discontinuous letters. In doing this, the previously silent lines are now made to speak. "The calligram aspires playfully to efface the oldest opposition of our alphabetic civilization: to show and to name; to shape and to say; to reproduce and to articulate; to imitate and to signify; to look and to read" (p. 21).

In Magritte's Treachery of Images, the text and the figure are separated by what Foucault calls alternately a crevasse, an uncertain foggy region, "the absence of a space, the effacement of the common place between the signs of writing and the lines of the image" (1983, p. 28). He illustrates this relationship by creating an imagined discussion between a teacher who is attempting to explain The Treachery of Images and his students. 
"This is not a pipe but a drawing of a pipe," "This is not a pipe but a sentence saying this is not a pipe," "The sentence 'this is not a pipe' is not a pipe," "In the sentence this is not a pipe this is not a pipe: the painting, written sentence, drawing of a pipe - all this is not a pipe." The pipe and the text do not enter into any kind of stable relationship. What we do end up with though, is "the intersection within the same medium, of representation by resemblance and of representation by signs" (p. 34).

bpNichol worked with a variety of translational strategies that explored the space between resemblance and representation. "This business of seeing what's in front of you, of actually dealing with the reality of that surface and the marks that you place on it, is central to any notion of notation; i see it so i can say it" (2002, p. 358). The strategy of saying what can be seen was used by Nichol to generate sound performances from visual material. Nichol would read the marks on the page almost as a tape head would read the magnetic patterns on audiotape - the various patterns would serve as a source for the generation and modulation of a sound performance.

Speaking vision is a form of data mapping. The reading of visual information as auditory information maps the seen onto the performed sound through the visual and speaking apparatus of the performer. The optophonetic reading, a term and technique developed by Raoul Hausmann, is one in which the visual text is used by the performer to generate and modulate a phonetic performance (Scholz, 2001). Nichol's notion of notation is about creating resemblances between the visual text and the performance. Richard Cavell (2003), citing Marcel Duchamp points out that the optophonetic translation of what can be seen into to sound is a critical and participatory practice. It highlights the mediation of the reader and the reading. In addition to this, I would argue 


\section{DIGITIZING bpNICHOL}

that technological media informs this reading strategy. The gramophone, phonograph, film optical track, magnetic tape recorder all provide models for the optophonetic reading strategy as does the idea of digital data mapping.

There are two sound poetry compositions in The Complete Works, Interrupted Nap, performed by Nichol (Nichol, 1982) and White Sound, an original performance by Stephen Ross Smith. Both segments start with visual texts as the source for a sound performance. Using digital algorithms to create and modify animations based on audio, a method called audio reactive animation, I inverted the optophonetic see-and-say strategy. In both pieces, the sounds of the performances are algorithmically connected to various visual parameters to generate resemblances between the performance and the visuals.

Interrupted Nap is a recording from the 1982 collection, Ear Rational (Nichol, 1982). In it we hear snippets of a narrative, "Once upon a time...", which are interrupted by bursts of nonsensical vocal sound. It sounds as if the narrator is having difficulty telling the story. The word "aphasia", which describes the inability to make sense in language or of language, appears at the end of the piece. Aphasia accurately describes the experience of listening to this work. Either the listener has receptive aphasia, or the narrator has expressive aphasia. The recording creates a tension between a narrative and incomprehensible vocal noise.

The source text is a series of visual panels (Nichol, Interrupted Nap, 1990) that appear to have been reproduced from pages on which someone has used a magic marker to write. The marker has bled through each page to the subsequent pages onto which new material has then been written. In a traditional sense of reading, the panels are no longer legible. Nichol reads the text as if his visual and speaking faculties operate like the head 
DIGITIZING bpNICHOL

of a magnetic tape recorder, reading and speaking the information on the page including the "noise" from the marker bleed.

Figure 9. Interrupted Nap (Nichol, 1990).

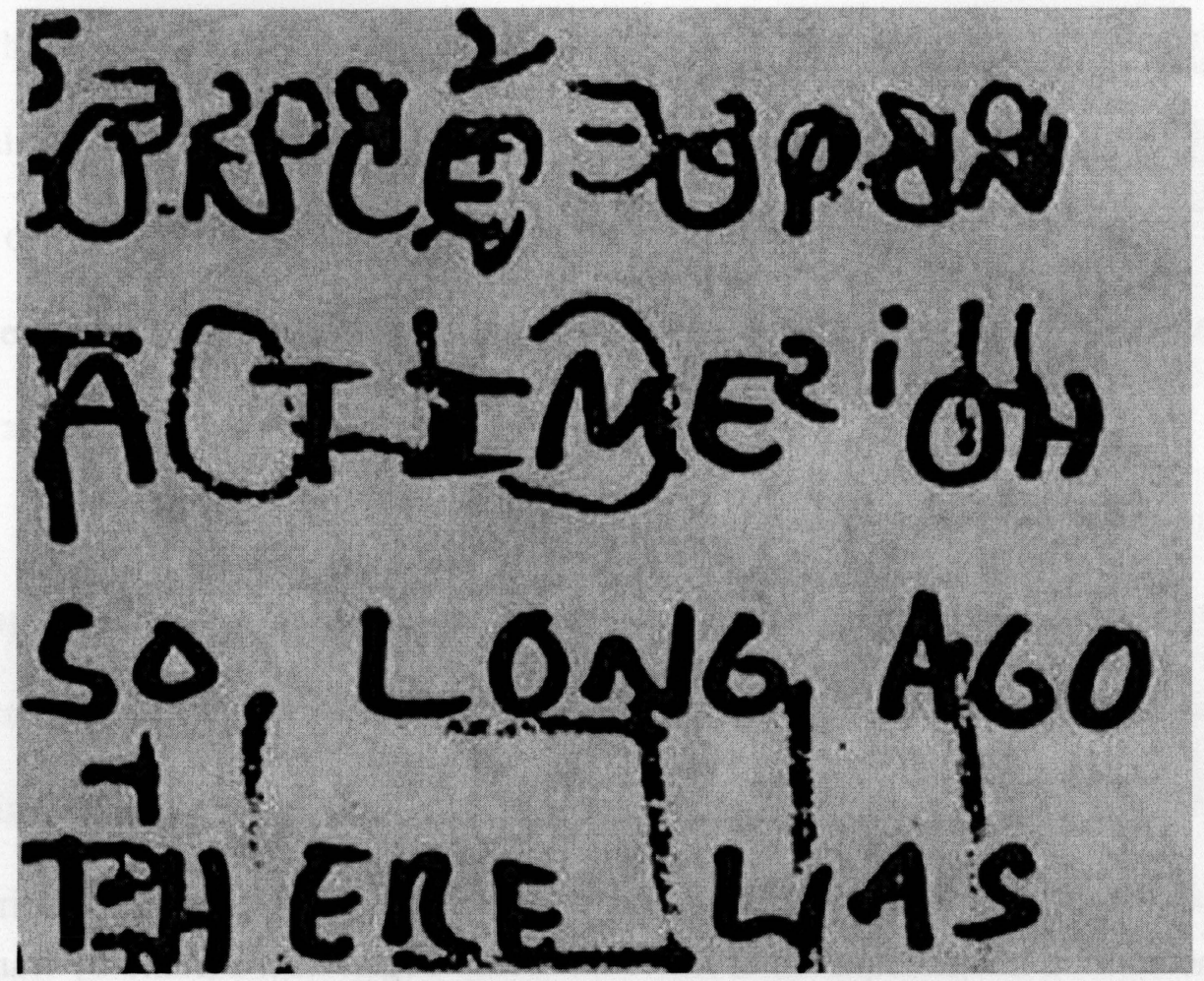

The visual marker bleed is like "print through" on an analog audiotape that has been sitting on the shelf for a decade or more, in which the surrounding layers of a magnetic tape on a spindle "print" their magnetic patterns onto each other creating a distortion of the original recording. Here the distortion of the text on the page is reproduced in the optophonetic reading of the text.

The title of the poem suggests an interruption between napping and waking. It is the aphasiac moment in which sense and nonsense are superimposed. Fredrick Kittler (1999, p. 45) sees this as the reality of modern media technology. For Kittler, white noise is the backdrop of all technological media, which, previous to 1900 , could not be recorded 
DIGITIZING bpNICHOL

(ibid.). In Interrupted Nap, Nichol inscribes on the page the noise and distortion introduced by technological media. In the performance of this "text", he merges sense and noise to create an aphasic moment.

Figure 10. Interrupted Nap from The Complete Works (Stephenson, 2012).

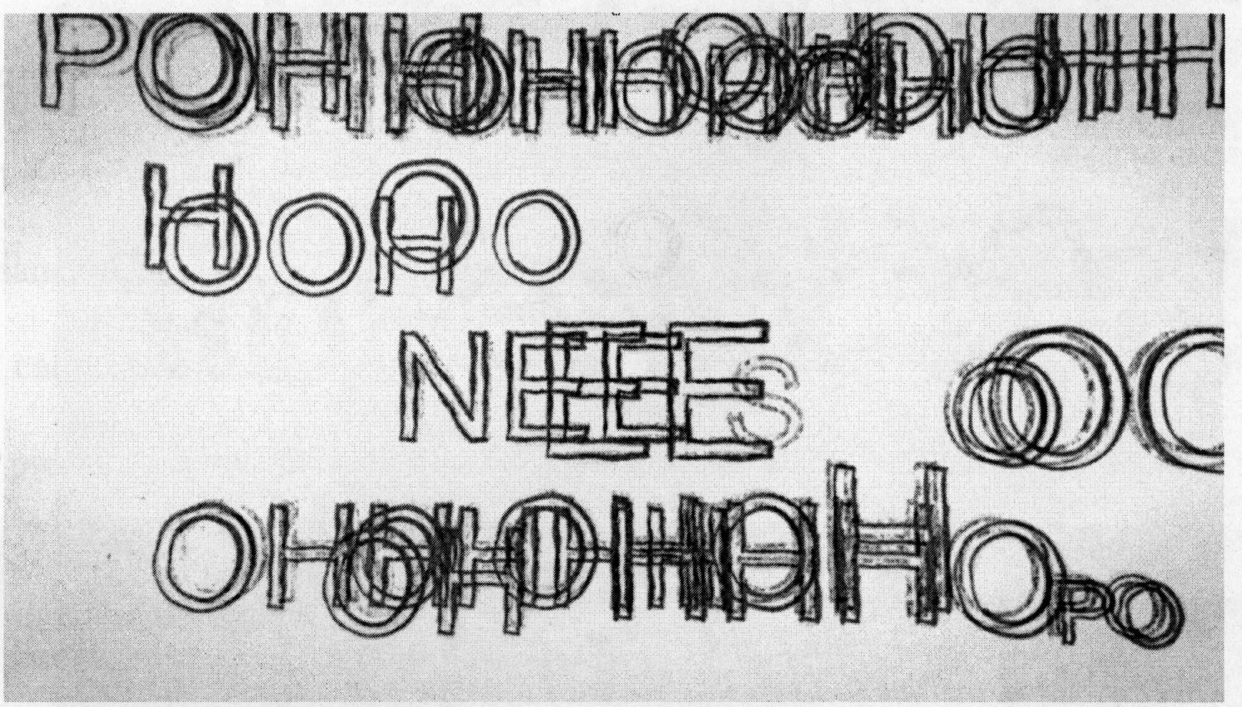

The moving image sequence of Interrupted Nap began with a frame-by-frame phonetic transcription of Nichol's performance of the text. The strategy was to listen to the sound performance and derive a phonetic text from what could be heard in the performance-reversing Nichol's methodology of reading what he could see by notating what could be heard. Using a combination of Cinema 4D (C4D for short) for the animation and Adobe After Effects for the compositing, the visual and material qualities of the original text were reinterpreted in the animation. This was accomplished using a custom procedural shader I built in Cinema 4D that mimics the kinds of textures and imperfections that would be introduced if one were to trace out a letter using a marker on successive frames. From here, I wrote a series of algorithms using C4D's internal scripting languages and used them to animate the stanzas of the poem by mapping the 
DIGITIZING bpNICHOL

modulations of the audio recording to animation parameters such as rotation, scale, velocity and transparency. The algorithm reads the frame-by-frame phonetic transcript of the poem to generate the letterforms and then animates these letterforms based on an algorithmic scheme that is modulated by the sound. There is no manual manipulation in this animation - it is entirely procedural (created by algorithms) and modulated by the sound of Nichol's voice. The final compositing of the animation is designed to introduce the artefacts and the noise of the original text by using imperfections in exposure, frame registration, and camera movement.

Each animated "stanza" of the poem explores a different way of creating an interruption of the reading: moving from left to right quickly, layering successive characters overtop one another, moving from bottom to top for example (Figure 10). Mapping the audio to the animation and visualizing the frame-by-frame phonetic transcript of the poem links what we are seeing to what has been said. Interrupted Nap uses the strategies of Nichol's original source text and performance to create a uniquely contemporary digital moving image strategy. Procedural animation provides a way of looking at Nichol's voice and allowing us to see what he said in a new way.

The white noise of technological media is the focus of Nichol's visual text, White Sound. It's a chap-book (Figure 11) that contains pages filled with layers of the rubber stamped words "white sound" set against the backdrop of degraded photocopies of images created by printing blank mimeo plates, stamping empty sort rails, and pressing entire ink pads against the page.

Compositionally, we utilized the same technique with both the mimeograph \& the rubber stamprunning raw sheets of paper off the inked surface of the mimeo screen \& using the metal holder of 
a rubber stamp set to create the lines $\&$ circles. then of course there was the visual insistence of the "white sound" chant. we were working with visible analogies to machine noise \& using the binding \& folding action of the book/machine to break up and repeat certain areas of texture." (Nichol, 1976)

Figure 11. White Sound (Nichol, 1976).
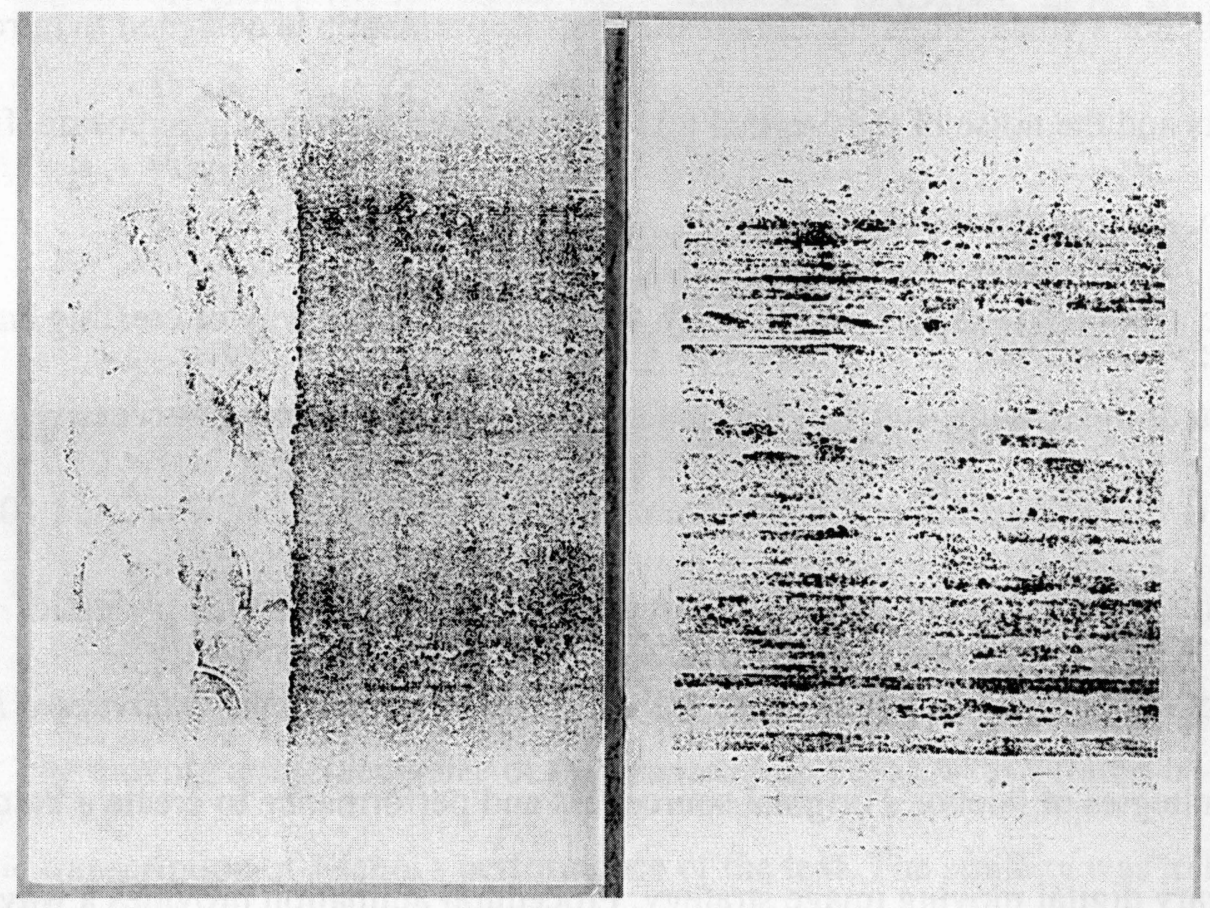

Interspersed within the pages are sheets of semi-transparent colour tissue that act as a filter through which the background text can be viewed. The artefacts and noise introduced through the photocopy process are recorded on the pages of the book.

In The Complete Works, Steven Ross Smith performs White Sound as sound poetry. It is, in effect, a variation of a printed variation by Ganglia Press (1976), of an original limited edition of which only two were created by bpNichol and David Aylward in 1966. The performance enacts the organic "generation loss" depicted in the text. The term generation loss is used to describe the noise introduced by duplicating content in 
analog media-each successive copy (generation) introduces more noise, decreasing the quality, or signal to noise ratio. In the case of White Sound, however, signal to noise is inverted so that the noise is the signal. Accordingly, the text gains quality in each successive generation.

Figure 12. White Sound from The Complete Works (Stephenson, 2012).

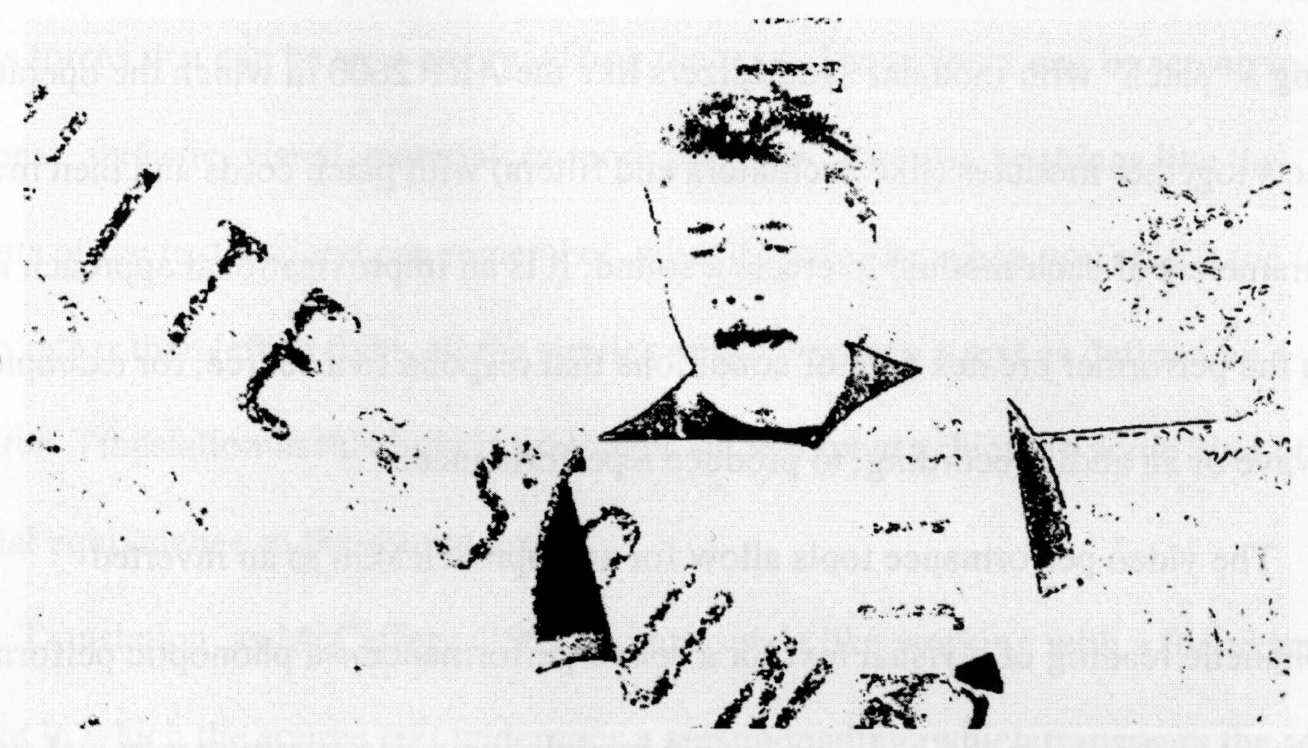

Using "hardwired patches" that combine algorithms created in Apple Computer's Quartz Composer programming language and the video performance software VidVox VDMX, the film version of White Sound is a document of a real-time video performance. VDMX allows the user to mix, process, animate and sequence multiple streams of video in real-time. There are two unique things about this package. Firstly, it allows for any parameter to be mapped to a data source. This data source can be an audio analysis, an oscillator, or a custom coded data source, for example a looping permutation of a set of predefined numbers. Secondly, custom-coded data sources, visual plug-ins, and animation generators can be built using Quartz Composer. Quartz Composer is a nodebased programming environment like Max/MSP, Pure Data, vvvv and others. 
DIGITIZING bpNICHOL

I used VDMX for the sequencing, layering, audio analysis, data mapping and playback. Quartz Composer was used to create custom filtering and logic for doing things like triggering events at specific video clip times, toggling parameters, and generating $\min / \mathrm{max}$ random values. The workflow can be imagined as a series of interconnected modules that create, modify, layer and output visuals. This method of working is akin to creating a "patch" with modular synthesizers like the ARP 2600 in which the operator connects together modules (like oscillators and filters) with patch cords and then modifies the parameters of each module to create a sound. It is an improvisational approach in which the performer creates a set of conditions that respond to a source, for example a sine wave or an audio recording, to produce a performance.

The video performance tools allow for an approach akin to an inverted optophonetic reading of a visual text for a sound performance-a phonoptic performance. A segment of the audio can be looped while modulating video parameters in real-time to choose a set of conditions that read the audio in a way that creates a visual resemblance to the performance. This mirrors the methodology of the sound poetry performance, which is an improvised translation of the marks on the page as sound. Further, as Richard Cavell highlighted earlier, this is a participatory and critical practice. There is necessarily a re-reading and re-inscription of the source material. In this sense, this version of White Sound is a remix of the original.

\section{In Remixing bpNichol: Direct Dealing and Recombinatory Art Practices} (Forthcoming 2012), I argue that improvisation, deconstruction, fragmentation and free play are key aspects of bpNichol's poetics and that these strategies form the basis of the working methodology of The Complete Works. In many respects, the translational 
DIGITIZING bpNICHOL

approach I use in my project can be seen as a remixing of Nichol's work in digital moving image. Nichol and Steve McCaffery, in Rational Geomancy: The Kids of the Book-Machine The Collected Research Reports of the Toronto Research Group (1992), discuss translation as a creative act in which the signs in the destination text are aligned to recreate "perceived stresses" from the source text. They view these stresses as the various forces that can be seen as organizing the text. The stresses can be semantic, emotional, acoustic, visual, material, or more playfully, they can be things like the elements of the text a friend can remember, what it looks like when you read it top to bottom rather than left to right, all the similes of the words in a text as defined by a thesaurus. Translation in this light is no longer an attempt at achieving some kind of essential equivalence to the source text.

Translation, as McCaffery (1992) points out, is like working with a found text. It is an act in which the source text undergoes a seeing/reading, which transports the source into a new context. This act of seeing implicates the translator and the moment of translation as active agents in the translation. It highlights the translation as an on-going process that develops with the translator and his or her specific context. Translation is a creative act that resonates with the contemporary practice of remixing.

Digital image making technology allows the video maker to create a new work by accessing and recombining audio, visual, and textual materials. While this was possible with previous technologies, it was very expensive and laborious. It can now be accomplished economically with an ease that was not possible before. Quoting material has long been a cornerstone of textual creative practices (Lessig, 2008). Kenneth Goldsmith (2011), in a discussion of Benjamin's Arcades Project suggest that writers 
DIGITIZING bpNICHOL

have been building new work on networks of previous texts since the beginning of writing and, as such, one could see all cultural material as shared. Paul D. Miller, aka DJ Spooky, argues that the remix is a compositional method in and of itself: "This is a world in which all meaning has been untethered from the ground of its origins and all signposts point to the road that you make up as you travel through the text" $(2004$, p. 5). Rather than producing a work based on the context of the original material, the selection and combination of materials are determined by the context of the work at hand.

Nichol drew on a wide range of sources for his work. In doing this he was creating poetic remixes based on these materials, including his immediate surroundings. He narrativizes this remixing approach in this excerpt from The Martyrology:

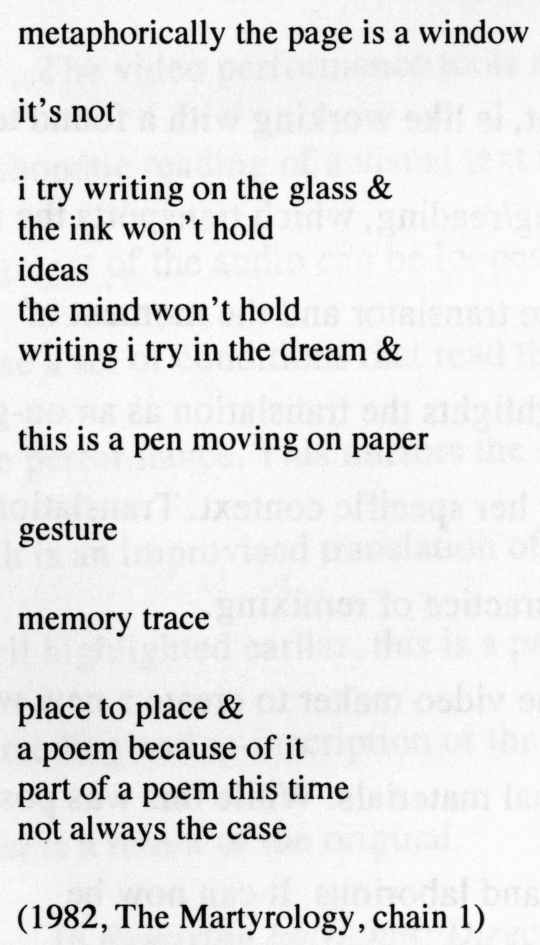

The poem, for Nichol, is built in the movement from element to element-in travel, in memory, and in the movement of words on the page during the act of writing and 
DIGITIZING bpNICHOL

reading. The specific quality of the movement produces the poem or, in this instance, a part of a poem.

Figure 13. The Page is a Window from The Complete Works (Stephenson, 2012).

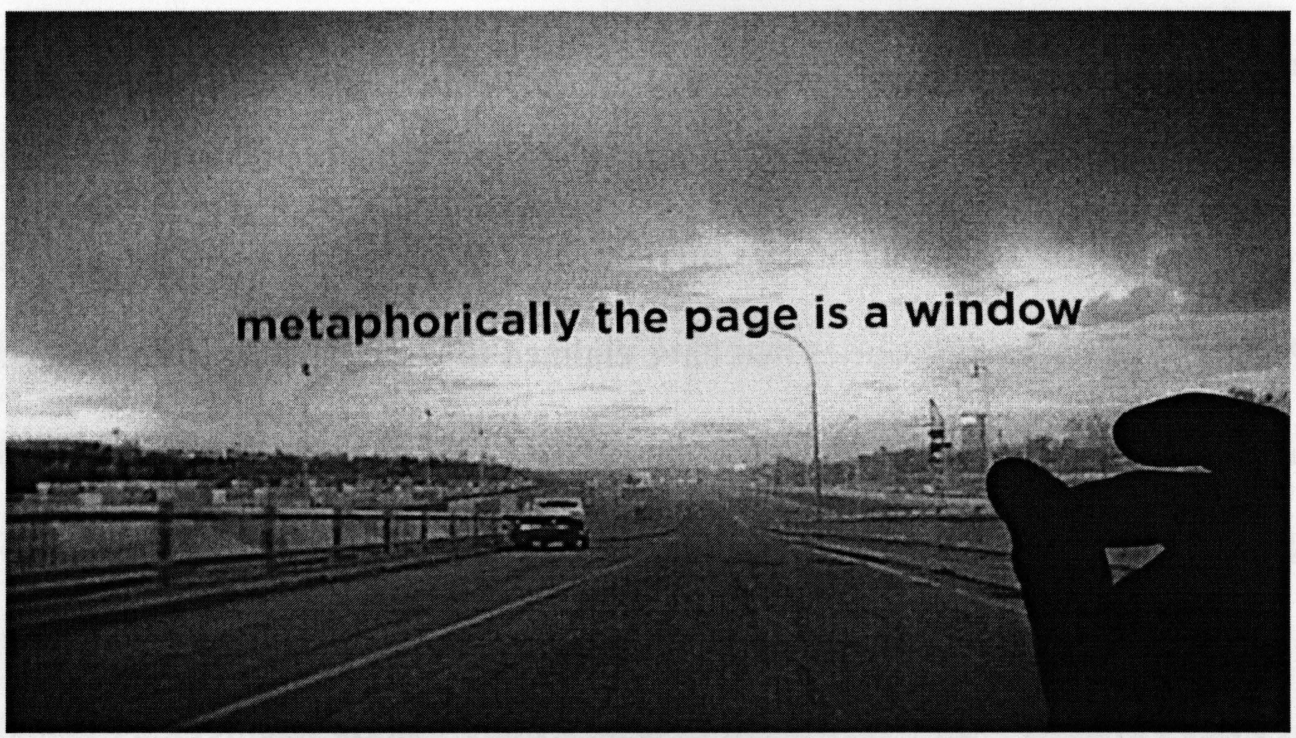

In The Complete Works, this segment from The Martyrology uses a hands-on compositing technique to combine the text and picture to create a remix of the original recording and text. The sequence is based on travel footage that was edited together to work with an energetic music track. The recorded performance by Nichol was divided into segments and rearranged for rhythmic and thematic emphasis. The compositing uses lines from the poem printed onto transparent film and then placed, by hand over the moving image sequence as it plays back on a monitor (Figure 13). This process is reshot and edited together to create the final composition.

The Complete Works involves re-reading and re-inscribing Nichol's poetry. The Page is a Window segment physically rearranges and recombines the text to create something new - literally along a "road that you make up as you travel through the text" (Miller, 2004, p. 5). In this sequence, the opaque marks of the text, and the visible 
DIGITIZING bpNICHOL

manner in which they are placed on the image make it impossible to see them as being transparent. The page cannot metaphorically be a window because there is always the precipitate of the materiality of the text and the network of cultural and political contexts contained within.

The True Eventual Story of Billy the Kid remixes the story of Billy the Kid along a very different axis. As Stephen Scobie surveys in In Search of a Character (1972), there are a plethora of books and stories that have claimed to write the true Billy with titles like The True Life of Billy the Kid, by Don Jenardo from 1881; The Authentic Life of Billy, the Kid, by Pat Garrett from 1882; The Real Billy the Kid, by Miguel Otero from 1936; The True Story of Billy the Kid, by William Lee Hamlin from 1959. Nichol's Billy is based on a joke turned rumour-Billy was mean because he had a short dick. Scobie argues that Nichol's Billy is a "dismissal of any possibility of objective truth in reporting; it insists that any observer changes what he sees as soon as he attempts to express it. Language does not report reality: it creates reality" (1972, p. 41). The truth, for Nichol, is in the telling. All other stories about Billy, historical and otherwise are untrue next to his telling.

The Complete Works combines a variety of materials to create a remix of Nichol's poetic remix of the story of Billy the Kid. The performance by Stephen Scobie is intercut with variously treated visuals based on a Billy the Kid TV series, an example of which is Billy The Kid Wanted (Newfield, 1941), produced between 1940 and 1946 by the Producers Releasing Corporation. This material now exists in the public domain. In addition, the music is a radical cover version of The Prodigy recording Music for the Jilted Generation by Ergo Phizmiz (2010). He covered the recording in a manner that 
DIGITIZING bpNICHOL

sounds lo-fi and homemade which is very different than the high tech, expensive production of the original. The original Music for the Jilted Generation by The Prodigy was a protest against the crackdown by the law in England on raves and rave music. The recording is exemplified in the piece Their Law which begins with a sample "Fuck them and Their Law". Phizmiz's covers enact a protest against the notion of a true version, "I want to cover something that's a real "sacred cow". Do you know the album "Music For the Jilted Generation" by The Prodigy? In the UK it kind of defined a generation, early 90s..." (upitup.com, 2012).

Nichol's Billy goes against the traditional portrayal of Billy the Kid as a tough, masculine outlaw. Juxtaposed against the television cowboy series, Nichol's story recontextualizes the images of Billy the Kid. While the TV series depicts Billy as a hero of the people and a misunderstood fugitive, Nichol asks if he could have been called "Billy the Man", or "Bloody Bonnie" and if so, would he have bothered having a faster gun. In so doing, we read the picture outside of the original context. When set against Nichol's poem, the Billy of television becomes the faster gun because he was not Billy the Man.

Nichol's Billy is about circulation of Billy the Kid as a text. Billy is a figure that occupies a prominent place in stories about the outlaws of the American west. In the various "tellings" of Billy's story, new versions of Billy the Kid are created. The story is a site for the endless recasting and recombination of Billy the Kid. Nichol's Billy is like Warhol's Jackie Kennedy, Marilyn Monroe, Elvis, or Mao. As Kenneth Goldsmith (2011) describes, Warhol's iconic images of famous people are positioned within Barthes' notion of a "tissue of citations, resulting from the thousand sources of culture" 
DIGITIZING bpNICHOL

(as cited in Goldsmith, 2011, p. 149). As Nichol puts it, "The True Eventual Story is that Billy the Kid shot it out with himself, there was no one faster" (1978, The True Eventual Story of Billy the Kid, chap. 4). Billy, as a text, connects to thousands of places in culture and that number continues to grow. The True Eventual Story of Billy the Kid is that he cannot remain stable because he is produced by ever changing layers quotations. "The True, Eventual Kid" is a thing of rumour.

In many respects, Nichol himself occupies an unstable position in much the same way as Billy the Kid does, though the rumours are of a different sort. He was a focal point for the Canadian avant-garde poetry scene, and his work continues to be widely circulated and cited. There are critical battles surrounding his work between those that link his texts to the memory of Nichol The Man, highlighting the expressiveness in the work and Nichol's generosity of spirit (Smith, 1998; Bowering \& Ondaatje, 1994; Niechoda, 1988; Scobie, 1984; Barbour, 1980) and those that advocate for a more radical Nichol, directing readers to Nichol's more challenging conceptual work and arguing for a more critical approach to reading his work (Bök, 1998; Wershler-Henry, 1998; Davey, 1986; McCaffery, 1988). In addition, there is a great deal of production surrounding his work: the aforementioned critical texts, collected works readers (Bowering \& Ondaatje, 1994; Wershler \& Emerson, 2007), books of poems dedicated to his memory, films, musicals, theses, dissertations, and this project and paper. The Complete Works started with the idea of translating his work to moving images. This translation has involved a reading that opens up an active participation in the texts. It is quite clear through this process that the work of reading and translating Nichol absolutely resists closure. 
DIGITIZING bpNICHOL

Gertrude Stein said that reading does not give one the full sense of what a text is, "I always say that you can not tell what a picture really is or what an object really is until you dust it every day and cannot tell what a book is until you type it or proof read it. It then does something to you that only reading can never do" (1944, p. 94). Reading Nichol's work through this digital cinema project and paper has revealed that Nichol's work is not poetry in the traditional, expressive sense, but a network of practices and writing processes. As Steve McCaffery (1986) points out, contemporary writing is not about what it means, but how it works. This does not, however, exclude emotional content from poetry. As Nichol pointed out earlier, emotion is found in the writing practice itself. Kenneth Goldsmith elaborates on this, "far from being coercive or persuasive, this writing delivers emotion obliquely and unpredictably, with sentiments expressed as a result of the writing process" (2011,p. 4). While Goldsmith is describing his "uncreative" practice, and it would not be accurate to paint Nichol's entire oeuvre with this description, Nichol's work largely intersects with this notion of a process-based writing.

The Complete Works uses Nichol on Nichol. Through the staggering catalog of techniques, genres and concerns in his work, Nichol points always to the reader and the instant of reading. As Roland Barthes highlights, "The reader is the space on which the quotations that make up a writing are inscribed without any of them being lost; a text's unity lies not in its origin, but in its destination" (1988, p. 148). Nichol's work develops a self-reflexive tension between the poem, in all of its material, structural, and pragmatic features and the reader as a participant in the creation of meaning. This tension opens an interpretive space that is like Foucault's "uncertain foggy region" between text and image 
DIGITIZING bpNICHOL

or Cavell's "multidimensional dynamic of figure and ground". In it we are able to see the workings of the text as we are faced with a virtually endless play of our own interaction with the poem. The Complete Works makes an attempt to open up this space in moving images.

The ability to treat the image as system of discrete elements, as opposed to a flattened semantic field using digital image making technologies has allowed me to align the methods of my project to bpNichol's methods and maintain his insistence on the link between form and emotional content and writing as a process of creating meaning. In doing this, Nichol's work has provided a way of investigating and describing not only my digital practice, but also the practice of translation and the nature of the poetic writing. This has had a profound effect on the way that I approach making and engaging images. This project has made it clear that contemporary poetics, Nichol's and otherwise, provide a method to create, investigate, and critique contemporary digital image making practices. 


\section{REFERENCES}

Archer, B. (1979). Design as a Discipline. Design Studies, 1(1), 17-20.

Attridge, D. (1984). Language as Imitation: Jakobson, Joyce, and the Art of

Onomatopoeia. $M L N, 99(5$, Comparative Literature), 1116-1140.

Barthes, R. (1988). The Death of the Author. Image, Music, Text (S. Heath Trans.).

(Noonday Press ed., pp. 142). New York: Noonday Press.

Benveniste, E. (1971). The Nature of Pronouns. Problems in General Linguistics

[Problèmes de Linguistique Générale.] (pp. 217). Coral Gables, Fla.: University of Miami Press.

Bernstein, C. (1992). A Poetics. Cambridge, Mass.: Harvard University Press.

Block, F. W. (2007). Digital Poetics or On The Evolution of Experimental Media Poetry.

In E. Kac (Ed.), Media poetry : An International Anthology (pp. 229). Bristol, UK ;

Chicago: Intellect.

Borges, J. L., \& Hurley, A. (1998). Collected Fictions [Short stories.] . New York, N.Y., U.S.A.: Viking.

Botting, F. (1994). Relations of the Real in Lacan, Bataille and Blanchot.

SubStance, 23 (1, Issue 73), pp. 24-40.

Cavell, R. (2003). McLuhan in Space : A Cultural Geography. Toronto: University of

Toronto Press.

Cayley, J. (1998). Of Programmatology. Mute [Online], (Fall)

Cayley, J. (2004). Literal Art. Electronic Book Review, , March 26, 2008.

De Freitas, N. (2002). Towards a Definition of Studio Documentation: Working tool and

Transparent Record. Working Papers in Art and Design, 2, November 21, 2008.

De Freitas, N. (2007). Activating a Research Context in Art and Design Practice.

International Journal for the Scholarship of Teaching and Learning, 1(2), December

2, 2008.

Dilnot, C. (1999). The Science of Uncertainty: The Potential Contribution of Design

Knowledge. Paper presented at the Doctoral Education in Design, Hong Kong

Polytechnic University. Retrieved 10/06, 2010 from https://www.jiscmail.ac.uk/cgi-

bin/filearea.cgi?LMGT1=PHD-DESIGN\&a=get\&f=/dilnot.rtf

DJ Spooky That Subliminal Kid. (2004). Rhythm Science. Cambridge, Mass.:

Mediawork/MIT Press.

DJ Spooky That Subliminal Kid. (2008). Sound Unbound : Sampling Digital Music and Culture. Cambridge, MA: MIT Press.

Foucault, M. (1983). This Is Not a Pipe. Berkeley: University of California Press.

Golding, A. (2006). Language, Writing, Digital Poetics, and Transitional Materialities. In

A. K. Morris, \& T. Swiss (Eds.), New Media Poetics : Contexts, Technotexts, and

Theories (pp. 249). Cambridge, Mass.: MIT Press. 
DIGITIZING bpNICHOL

Goldsmith, K. (2011). Uncreative Writing: Managing Language in the Digital Age. New York: Columbia University Press.

Higgins, D. (1987). Pattern Poetry: Guide to an Unknown Literature. Albany: State University of New York Press.

Kittler, F. A. (1999). Gramophone, Film, Typewriter [Grammophon, Film, Typewriter.] . Stanford, Calif.: Stanford University Press.

Lacan, J. (1966). The Insistence of The Letter in The Unconscious. Yale French Studies, 36-37, 112-147.

Lessig, L. (2008). Remix : Making Art and Commerce Thrive in the Hybrid Economy.

New York: Penguin Press.

Manovich, L. (2006). Image Future. Animation, 1(1), 25-44.

Manovich, L. (2007). Understanding Hybrid Media. In B. Hertz (Ed.), Animated Painting (pp. 139). San Diego: San Diego Museum of Art.

Marshall, T., \& Newton, S. (2000). Scholarly Design as a Paradigm for Practice-Based Research. Working Papers in Art and Design, 1, November 16, 2008.

McBride, S. (2008). Web Draws on Comics. Wall Street Journal Online, Retrieved 02/02, 2012, from http://online.wsj.com/article/SB121634908179464605.html

McCaffery, S. (1986). North of Intention : Critical Writings 1973-1986 (1st ed.). New York; Toronto: Roof Books; Nightwood Editions.

McCaffery, S., Nichol, B. P., \& Toronto Research Group. (1992). Rational Geomancy: The Kids of the Book-Machine: The Collected Research Reports of the Toronto Research Group, 1973-82. Vancouver: Talonbooks.

McCloud, S. (1994; 1993). Understanding Comics: [The Invisible Art] (1 HarperPerennial ed.). New York: HarperPerennial.

McLuhan, M. (1994). Understanding Media : The Extensions of Man (1st MIT Press ed.). Cambridge, Mass.: MIT Press.

Miki, R. (1988). Tracing the Paths : Reading [does not equal] Writing the Martyrology. Vancouver: Talon Books.

Morris, S. (2003). The Royal Road to The Unconcious. York, England: Information as Material

Morris, S. (Director). (2003). The Royal Road to the Unconcious. [video], Retrieved 02/10, 2012, from http://informationasmaterial.com/? $\mathrm{p}=476$

Morris, S. (2005). The Royal Road to The Unconcious - Beyond Meaning. Art \&Text: Inscription, (11), 10/10/2010.

Newfield, S. (1941). Billy The Kid Wanted. [video], Hollywood: Producer's Releasing Corporation.

Nichol, B. P. (1973). bpNichol. [phonotape]. Toronto: High Barnet.

Nichol, B. P. (1974). Love : A Book of Remembrances. Vancouver: Talonbooks.

Nichol, B. P. (1976). White Sound: A Variant. Toronto: Ganglia Press. 
DIGITIZING bpNICHOL

Nichol, B. P. (1978). Craft Dinner: Stories \& Texts, 1966-1976. Toronto: Aya Press. Nichol, B.P. \& Webb, P. (n.d.) [c. 1980]. [radio interview]. Toronto: CBC Radio.

Nichol, B. P. (1982). Ear Rational. Milwaukee, WI, USA: Membrane Press.

Nichol, B. P. (1982). The Martyrology, book 5. Toronto: Coach House Press.

Nichol, B. P. (1985). Zygal : A Book of Mysteries and Translations. Toronto: Coach House Press.

Nichol, B. P. (1990). Art Facts : A Book of Contexts., Tucson, Ariz.: Chax Press.

Nichol, B. P. (2002). Meanwhile : The Critical Writings of bpNichol. Vancouver: Talonbooks.

Nichol, B. P., \& David, J. (1980). Selected Writing : As Elected. Vancouver: Talonbooks.

Nichol, B. P., \& Miki, R. (2002). Meanwhile: The Critical Writings of bpNichol. Vancouver: Talonbooks.

Nichol, B. P., \& Niechoda, I. (1993). Truth : A Book of Fictions. Stratford, Ont.: Mercury Press.

Nichol, B. P., Wershler-Henry, D. S., \& Emerson, L. (2007). The Alphabet Game : A bpNichol Reader (1st ed.). Toronto: Coach House Books.

Niechoda, I. (1992). A Sourcery for Books 1 and 2 of bpNichol's The Martyrology. Toronto: ECW Press.

Perloff, M. (2010). Unoriginal Genius: Poetry by Other Means in the New Century. Chicago ; London: The University of Chicago Press.

Phizmiz, E. (2010). Music for a Jilted Generation , Retrieved 02/10, 2012, from http://www.upitup.com/catalogue/release.php?cat_id=34

Rose, G. (2006). Visual Methodologies (2nd ed.). Thousand Oaks, CA: SAGE Publications Ltd.

Scholz, C. (2001). Relations Between Sound Poetry and Visual Poetry: The Path From the Optophonetic Poem to the Multimedia Text. Visible Language, 35(1), 92-92.

Scobie, S. (1972). Two Authors in Search of a Character. Canadian Literature, (54), 37.

Scrivener, S. (2004). The Practical Implications of Applying a Theory of Practice Based Research: A Case Study. Working Papers in Art and Design 3, November 28, 2008.

Stein, G., \& Van Vechten, C. (1946). Selected Writings of Gertrude Stein. New York: Random House.

Stephenson, J. (2009). The Complete Works Working Papers - Mind Map. Retrieved 02/02, 2012, from http://justinstephenson.com/wp/cw-film-outline-2/cw-film-outline

Stephenson, J. (2009). The Complete Works Working Papers - Initial Collages. Message posted to http://justinstephenson.com/wp/2009/02/09/initial-collages

Stephenson, J. (2012). The Complete Works Working Papers. Retrieved 02/02, 2012 , from http://justinstephenson.com/wp

Stephenson, J. (Film Maker) (2012). The Complete Works. (Video). 
Stephenson, J. (Forthcoming 2012). Remixing bpNichol: 'Direct Dealing' and Recombinatory Art Practices. In R. Coombe, D. Wershler \& M. Zeilinger (Eds.), Dynamic Fair Dealing: Creating Canadian Culture Online. Toronto: University of Toronto Press.

Szczepanik, P. (2002). Intermediality and (Inter)media Reflexivity in Contemporary Cinema. Convergence, 8(4), 29-36.

Upitup.com. Upitup Notes on Music for a Jilted Generation. Retrieved 02/10, 2012, from http://www.upitup.com/catalogue/release.php?cat_id=34

Vision Research. About Vision Research, History of VRI. Retrieved 02/15, 2012, from http://www.visionresearch.com/About-VRI/History/ 